\title{
USING MOTION CAPTURE ANALYSIS FOR ASSESSING LOCOMOTION AFTER ARTHROSCOPIC ANTERIOR CRUCIATE LIGAMENT RECONSTRUCTION
}

\author{
Mozheyko EYu' ${ }^{1}$, Pavlov $\mathrm{AO}^{2}$, Chistov $\mathrm{MA}^{1}$, Khramchenko MA¹', Gurevich VA ${ }^{1}$
}

${ }^{1}$ Voino-Yasenetsky Krasnoyarsk State Medical University, Krasnoyarsk, Russia

${ }^{2}$ Federal Siberian Research and Clinical Center of FMBA, Krasnoyarsk, Russia

\begin{abstract}
An anterior cruciate ligament tear is one of the most common injuries to the capsular ligament apparatus of the knee necessitating operative treatment. Postoperatively, patients with anterior cruciate ligament injuries develop a pathologic gait pattern. Today, innovative diagnostic and rehabilitation methods for patients with gait disturbances associated with such injuries are in high demand. Below, we present a case of using 3D motion capture analysis for the personalized assessment of gait function in a patient with the reconstructed anterior cruciate ligament two months after surgery. The analysis revealed that the patient had a slower, shorter, wider step with longer step intervals than the healthy subject; the flexion and extension amplitude in the large joints of the operated leg was smaller than in the healthy contralateral leg. Motion capture analysis can be used to assess the postoperative dynamics in patients with anterior cruciate ligament tears.
\end{abstract}

Keywords: motion capture, anterior cruciate ligament, gait, postural disorders, rehabilitation

Author contribution: Mozheyko EYu formulated the hypothesis, proposed the design, defined the goals and objectives of the study, analyzed study results, wrote and edited the manuscript; Pavlov AO formulated the hypothesis and edited the manuscript; Chistov MA, Khramchenko MA searched the literature, analyzed study results, performed statical analysis and wrote the manuscript; Gurevich VA recruited the subjects, analyzed the results and performed statistical analysis.

Compliance with ethical standards: the study was approved by the Ethics Committee of Krasnoyarsk State Medical University (Protocol № $89 / 2019$ dated April 17, 2019).

$\square$ Correspondence should be addressed: Elena Yu. Mozheyko Prospekt Mira, 5, Krasnoyarsk, 660049, Russia; el_mozhejko@mail.ru

Received: 20.11.2021 Accepted: 13.12.2021 Published online: 28.12.2021

DOI: $10.24075 /$ brsmu.2021.063

\section{ИСПОЛЬЗОВАНИЕ ВИДЕОАНАЛИЗА ДВИЖЕНИЙ ПРИ ОЦЕНКЕ ЛОКОМОТОРНЫХ ФУНКЦИЙ ПОСЛЕ АРТРОСКОПИЧЕСКОЙ РЕКОНСТРУКЦИИ ПЕРЕДНЕЙ КРЕСТООБРАЗНОЙ СВЯЗКИ}

\author{
Е. Ю. Можейко ${ }^{1 凶}$ А. О. Павлов², М. А. Чистов ${ }^{1}$, М. А. Храмченко ${ }^{1}$, В. А. Гуревич ${ }^{1}$
}

${ }^{1}$ Красноярский государственный медицинский университет имени В. Ф. Войно-Ясенецкого, Красноярск, Россия

2 Федеральный сибирский научно-клинический центр Федерального медико-биологического агентства, Красноярск, Россия

\begin{abstract}
Разрыв передней крестообразной связки - одно из наиболее часто встречающихся повреждений капсульно-связочного аппарата коленного сустава, требующий оперативного лечения. В ходе длительного периода реабилитации после реконструктивных операций при данном виде травм у пациента формируется характерный двигательный паттерн. На сегодняшний день применение инновационных объективных методов диагностики и реабилитации двигательных нарушений при таких повреждениях актуально и востребованно. Представлен пример персонализированной реабилитационной оценки функции ходьбы пациента через два месяца после пластики передней крестообразной связки методом трехмерного видеоанализа движений. Выявлено нарушение паттерна ходьбы пациента: более медленный короткий редкий широкий шаг по сравнению с шагом здорового исследуемого; амплитуда сгибания-разгибания в крупных суставах оперированной нижней конечности меньше, чем в контрлатеральной нижней конечности пациента. Метод может быть использован в анализе динамики восстановительного лечения после оперативных вмешательств при разрыве крестообразных связок коленного сустава.
\end{abstract}

Ключевые слова: видеоанализ движений, передняя крестообразная связка, ходьба, постуральные нарушения, реабилитация

Вклад авторов: Е. Ю. Можейко - анализ результатов исследования, формулировка рабочей гипотезы, разработка дизайна исследования, определение цели и задач исследования, написание и утверждение рукописи для публикации; А. О. Павлов - формулировка рабочей гипотезы, утверждение рукописи; М. А. Чистов, М. А. Храмченко — поиск литературы, анализ результатов исследования, статистический анализ, написание статьи; В. А. Гуревич отбор единиц наблюдения, анализ результатов, статистический анализ.

Соблюдение этических стандартов: исследование одобрено этическим комитетом КрасГМУ (протокол № $89 / 2019$ от 17 апреля 2019 г.).

$\bigotimes$ Для корреспонденции: Елена Юрьевна Можейко

ул. Проспект Мира, д. 5, г. Красноярск, 660049, Россия; el_mozhejko@mail.ru

Статья получена: 20.11.2021 Статья принята к печати: 13.12.2021 Опубликована онлайн: 28.12.2021

DOI: $10.24075 /$ vrgmu.2021.063

An injury to the knee ligament apparatus is a pathology that involves one or more ligaments of the knee joint [1]. It is more prevalent among young able-bodied working-age men actively engaged in sports and exercise and is one of the most common traumatic and orthopedic injuries that compel the patient to seek medical help [1, 2].

The most common injury to the capsular ligament apparatus is an anterior cruciate ligament tear, affecting 30-35 people per 100,000 population [1].

Cruciate ligaments are fibrous bands of connective tissue that connect the femur and the tibia and limit excessive tibial mobility [3].
Most often, anterior cruciate ligament injuries are noncontact and occur during sudden knee joint rotation with the foot firmly planted [1, 4]. Many isolated ligament injuries are consequences of sports injuries caused by a rotational mechanism [5].

The following procedures are used to establish a diagnosis of anterior cruciate ligament tear: history taking, the Lachman test, the Anterior and posterior drawer tests of the knee, radiography of the knee joint (anterior, posterior and lateral views), and magnetic resonance imaging (MRI) of the knee joint [4].

Motion capture analysis (MCA) of gait provides valuable diagnostic data about the patient's locomotion patterns. It 
Table 1. Characteristics of gait speed and rhythm in the patient with injuries to the knee ligament apparatus and the healthy subject

\begin{tabular}{|l|c|c|c|c|c|c|}
\hline \multirow{2}{*}{ MCA parameters } & \multicolumn{2}{|c|}{ Patient with anterior cruciate ligament tear } & \multicolumn{4}{c|}{ Healthy subject } \\
\cline { 2 - 6 } & Left leg & Right leg & Both legs & Left leg & Right leg & Both legs \\
\hline Cadence (steps/min) & $94,4 \pm 2,91$ & $96,7 \pm 3,78$ & $95,5 \pm 3,51$ & $116,88 \pm 3,25$ & $117,56 \pm 4,12$ & $117,22 \pm 3,68$ \\
\hline Lead toe off (\% of the gait cycle) & $62,0 \pm 1,54$ & $62,9 \pm 2,87$ & $62,4 \pm 2,29$ & $60,10 \pm 1,79$ & $60,90 \pm 2,16$ & $60,60 \pm 1,97$ \\
\hline Initial contact, lead foot (\% of the gait cycle) & $49,80 \pm 1,62$ & $50,10 \pm 2,32$ & $49,90 \pm 1,96$ & $49,90 \pm 1,13$ & $50,10 \pm 1,75$ & $49,9 \pm 1,56$ \\
\hline Contralateral toe off (\% of the gait cycle) & $12,40 \pm 0,71$ & $12,80 \pm 0,96$ & $12,60 \pm 0,85$ & $9,80 \pm 0,94$ & $10,90 \pm 0,85$ & $10,50 \pm 0,96$ \\
\hline Single support time $(\mathrm{s})$ & $0,48 \pm 0,021$ & $0,46 \pm 0,038$ & $0,47 \pm 0,031$ & $0,41 \pm 0,026$ & $0,44 \pm 0,020$ & $0,43 \pm 0,025$ \\
\hline Double support time $(\mathrm{s})$ & $0,31 \pm 0,023$ & $0,32 \pm 0,020$ & $0,32 \pm 0,021$ & $0,21 \pm 0,023$ & $0,25 \pm 0,018$ & $0,23 \pm 0,021$ \\
\hline Step time $(\mathrm{s})$ & $0,64 \pm 0,031$ & $0,62 \pm 0,040$ & $0,63 \pm 0,036$ & $0,51 \pm 0,027$ & $0,56 \pm 0,028$ & $0,54 \pm 0,028$ \\
\hline Stride time $(\mathrm{s})$ & $1,27 \pm 0,042$ & $1,24 \pm 0,049$ & $1,26 \pm 0,047$ & $1,02 \pm 0,044$ & $1,12 \pm 0,040$ & $1,08 \pm 0,048$ \\
\hline Step length $(\mathrm{m})$ & $0,61 \pm 0,021$ & $0,62 \pm 0,016$ & $0,61 \pm 0,020$ & $0,68 \pm 0,033$ & $0,75 \pm 0,016$ & $0,72 \pm 0,027$ \\
\hline Step width $(\mathrm{m})$ & $0,20 \pm 0,018$ & $0,20 \pm 0,010$ & $0,20 \pm 0,015$ & $0,07 \pm 0,012$ & $0,07 \pm 0,010$ & $0,07 \pm 0,011$ \\
\hline Stride length $(\mathrm{m})$ & $1,21 \pm 0,023$ & $1,23 \pm 0,030$ & $1,22 \pm 0,029$ & $1,36 \pm 0,014$ & $1,51 \pm 0,0071$ & $1,45 \pm 0,011$ \\
\hline Walking velocity $(\mathrm{m} / \mathrm{s})$ & $0,95 \pm 0,042$ & $0,99 \pm 0,057$ & $0,97 \pm 0,053$ & $1,24 \pm 0,028$ & $1,44 \pm 0,025$ & $1,34 \pm 0,028$ \\
\hline
\end{tabular}

relies on the computer analysis of movements in which image acquisition is performed in a cableless, noncontact fashion [6].

Today, passive markers are widely used in clinical motion capture analysis. Passive markers are reflective sensors that are attached to the patient's body; the signals emitted by the sensors are captured by the video camera. The acquired data are transmitted to the computer for further processing. Finally, a report is generated that is subsequently used to analyze the linear and angular kinematics of the patient's movements [7].

MCA requires that, since a plane is defined by 3 points, there should be at least 3 reflective markers in the field of view of at least 2 cameras [8].

To measure the physical characteristics of the studied body segments, calibrating markers are attached to the subject. So far, reference standards have been elaborated for movements of the foot, tibia, femur, pelvis, spine, wrist, forearm, and shoulder [9].

At present, MCA is being actively used to uncover the mechanisms of noncontact injuries to the anterior cruciate ligament of the knee joint [10]. 3D MCA has been proposed for adoption into clinical practice as a tool for monitoring rehabilitation in patients with knee joint injuries and assessing the risk of re-injury [11].

The clinical case described below illustrates a personalized MCA-based assessment of locomotor function in the patient with anterior cruciate ligament tear.

\section{Clinical case}

Patient I., aged 21 years, was diagnosed with a complete anterior cruciate ligament tear of the left knee joint and a partial posterior cruciate ligament tear. On January 19, 2021 the patient
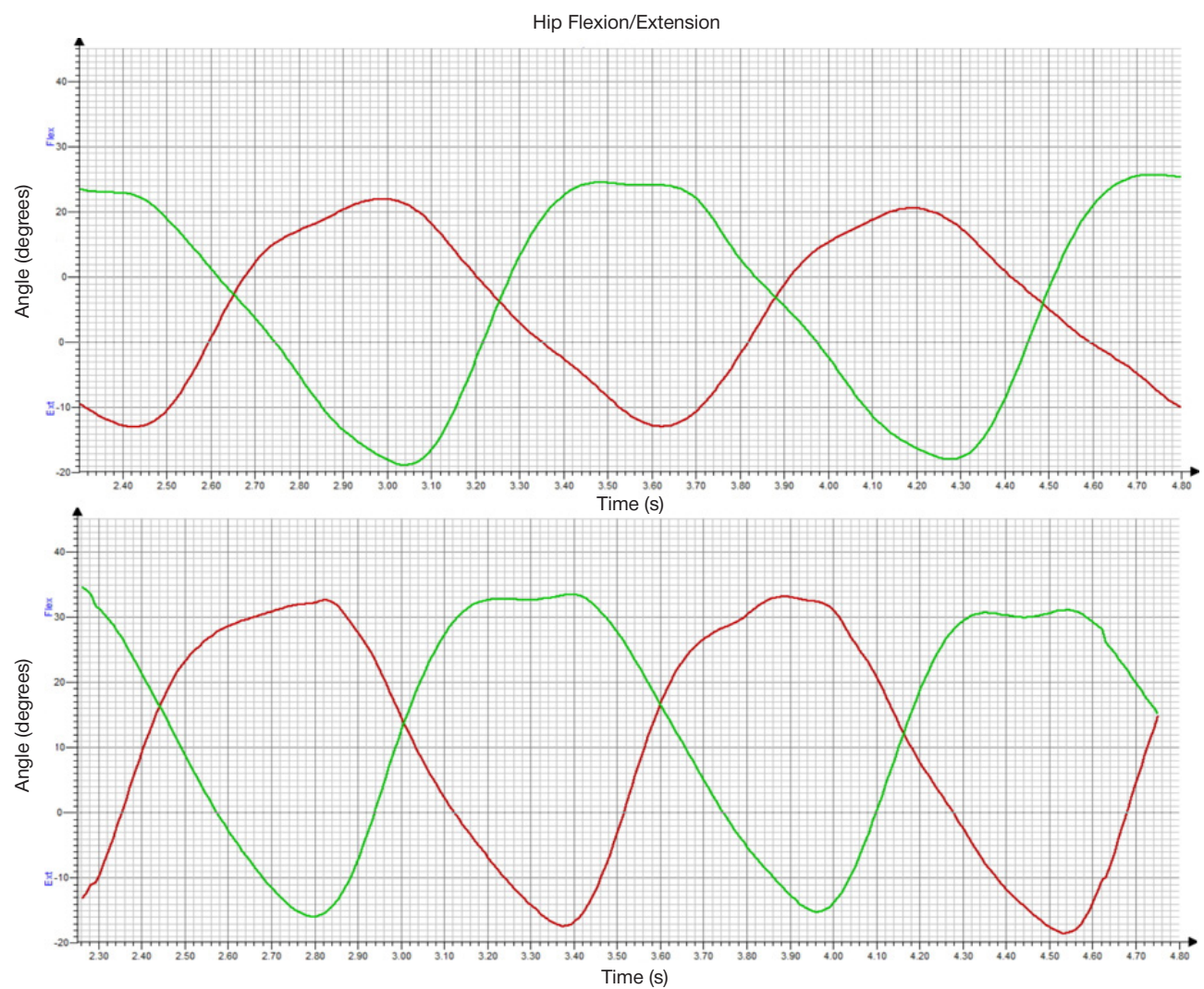

Fig. 1. Hip flexion and extension during one cycle in the patient with injuries to the knee ligament apparatus (top) and the healthy subject (bottom) 
Table 2. Mean hip flexion and extension angles and amplitudes during one gait cycle in the patient with injuries to the knee ligament apparatus and the healthy subject

\begin{tabular}{|c|c|c|c|c|}
\hline \multirow{2}{*}{} & \multicolumn{2}{|c|}{ Patient with injured knee ligament apparatus } & \multicolumn{2}{|c|}{ Healthy subject } \\
\cline { 2 - 5 } & Left leg & Right leg & Left leg & Right leg \\
\cline { 2 - 5 } & & \multicolumn{2}{|c|}{$\mathrm{Me}\left[\mathrm{P}_{25} ; \mathrm{P}_{75}\right]$} \\
\hline \multirow{2}{*}{ Angle 1 } & $-13,71$ & $-18,08$ & $-17,79$ & $-16,28$ \\
\cline { 2 - 5 } & {$[-15,03 ;-13,0]$} & {$[-18,59 ;-17,63]$} & {$[-16,79 ;-15,26]$} & {$[-16,63 ;-15,93]$} \\
\hline \multirow{2}{*}{ Angle 2 } & 23,3 & 24,43 & 34,52 & 32,66 \\
\cline { 2 - 5 } & {$[22,27 ; 24,48]$} & {$[23,62 ; 25,84]$} & {$[33,16 ; 35,19]$} & {$[31,07 ; 33,16]$} \\
\hline \multirow{2}{*}{$\Delta$} & 37,62 & 42,68 & 50,1 & {$[48,84$} \\
\hline
\end{tabular}

underwent arthroscopy of the left knee joint, resection of the remnant anterior cruciate ligament tissue, reconstruction of the anterior cruciate ligament with a peroneus longus autograft and autograft fixation with 19 PEEK Interference Screws (Arthrex; USA). The postoperative course was unremarkable. The patient received conservative treatment, which included antibiotics, analgesics, anticoagulants, and dressings. The knee joint was immobilized with a knee brace; the patient was using crutches for support when walking. On discharge, the patient's condition was satisfactory.

Preoperative MRI performed on December 3, 2020 revealed an impression fracture of the lateral femoral condyle; trabecular edema of the lateral tibial condyle, the intercondylar area and the medial femoral condyle; synovitis and suprapatellar bursitis; MR features of injury to the anterior cruciate ligament and ligamentitis of the medial collateral ligament; moderate degenerative changes of the anterior and posterior horns of the medial meniscus; periarticular soft tissue edema.

Subject V., aged 22 years, had no health complaints regarding their musculoskeletal system, no medical history of lower limb surgery or injury and was comparable with patient I in terms of their anthropometric characteristics.

The patient and the healthy subject were tested at the Laboratory of MCA at the Federal Siberian Research and Clinical Center (FMBA, Russia) using a Vicon Motion Capture Systems (Vicon; UK). The system consisted of 12 infrared T20 video cameras, 3 force plates, a Vicon GigaNet connectivity device, a computer with installed software for video signal capture and processing (Nexus ver. 1.7.15) and software for generating reports (Polygon ver. 3.5.1).

The testing included several stages. First, anthropometric measurements were taken to map the sizes of the patient's body segments to the computer model. Then, reflective markers were attached to the subject's bony landmarks. The patient and the subject were asked to walk at their usual speed on 3 force plates. During the test, the video cameras captured the spatial positions of the markers and the force plates recorded the ground reaction force. Each participant performed at least 10 gait cycles on 3 force plates.

The following changes in gait characteristics were observed in the patient with an anterior cruciate ligament tear vs the
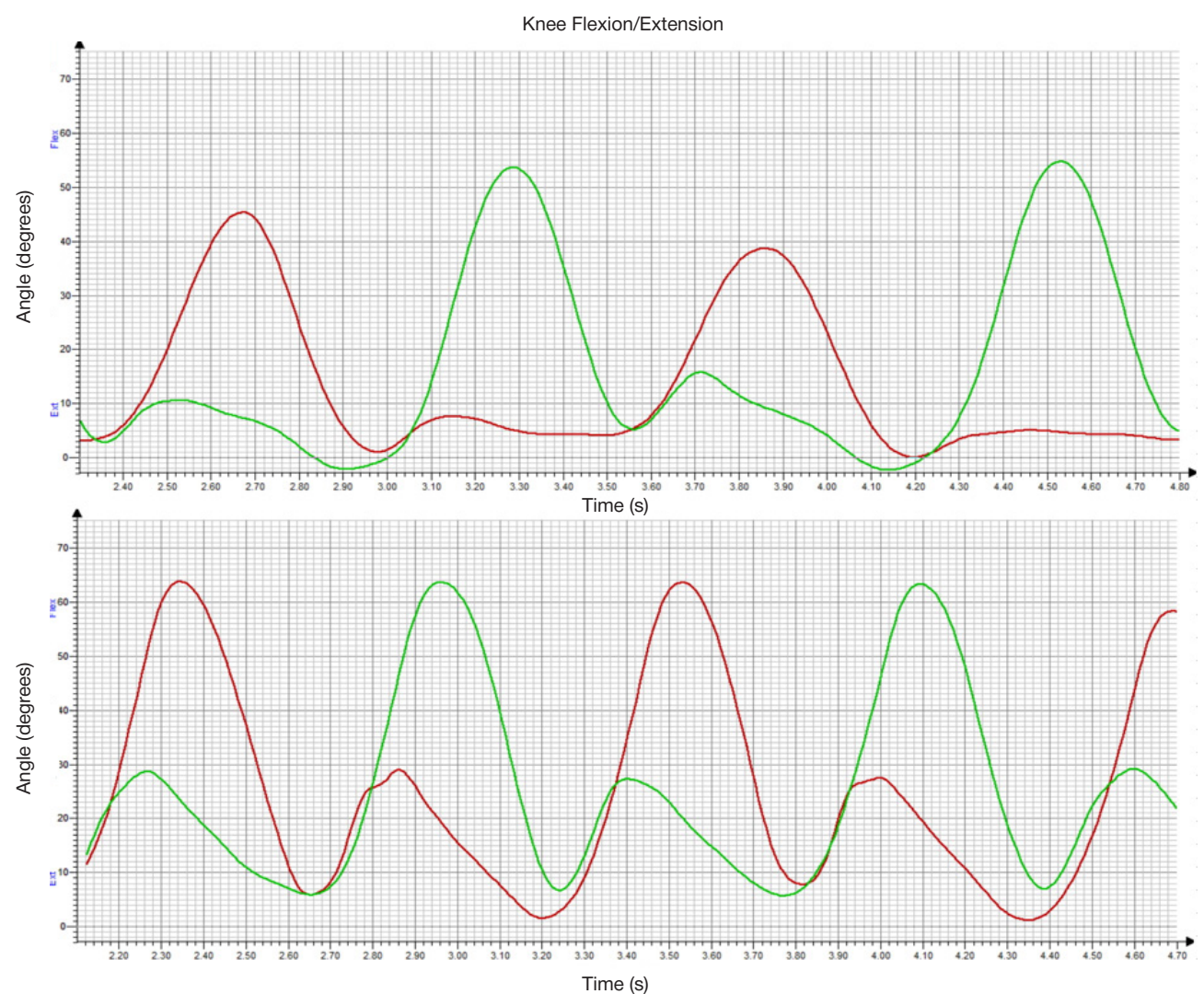

Fig. 2. Knee flexion and extension during one gait cycle in the patient with injuries to the knee ligament apparatus (top) and the healthy subject (bottom) 
Table 3. Mean knee flexion and extension angles and amplitudes during one gait cycle in the patient with injuries to the knee ligament apparatus and the healthy subject

\begin{tabular}{|c|c|c|c|c|}
\hline \multirow{2}{*}{} & \multicolumn{2}{|c|}{ Patient with injured knee ligament apparatus } & \multicolumn{2}{|c|}{ Healthy subject } \\
\cline { 2 - 5 } & Left leg & Right leg & Left leg & Right leg \\
\cline { 2 - 5 } & \multicolumn{3}{|c|}{ Me $\left[\mathrm{P}_{25} ; \mathrm{P}_{75}\right]$} \\
\hline \multirow{2}{*}{ Angle 1 } & 1,39 & $-2,89$ & 1,7 & 5,3 \\
\cline { 2 - 5 } & {$[1,04 ; 2,37]$} & {$[-3,32 ;-2,36]$} & {$[1,33 ; 2,26]$} & $6,02 ; 5,67]$ \\
\hline \multirow{2}{*}{ Angle 2 } & 45,07 & 52,82 & 61,89 & {$[63,4 ; 64,86]$} \\
\cline { 2 - 5 } & {$[42,61 ; 48,18]$} & {$[51,2 ; 54,59]$} & {$[60,82 ; 63,34]$} & 58,39 \\
\hline \multirow{2}{*}{$\Delta$} & 43,16 & 56,01 & {$[50,85$} & {$[57,73 ; 59,17]$} \\
\hline
\end{tabular}

healthy subject: significantly lower cadence and velocity, shorter step and stride lengths, longer step and stride times, longer single and double support phases, shorter toe-off phase for both lead and contralateral legs (Table 1).

The step width was significantly greater in the patient after anterior cruciate ligament reconstruction than in the healthy subject.

The initial contact time for the contralateral leg did not differ between the patient and the healthy subject.

The changes detected during the test suggest a gait pattern disturbance in the patient characterized by a slower, shorter, wider step with longer step intervals. We think that these changes are associated with 2 factors. First, the gait pattern may have undergone pathologic changes in the early postoperative period when the patient had to use crutches for locomotion and wear braces. Second, proprioception in the operated knee joint was impaired, which affected coordination in and between the muscles surrounding the knee joint.

3D MCA can be used to measure the amplitude of movement for different body parts at different stages of gait cycle and to compare the obtained data with the podometry data.
The amplitudes of movement of the hip, knee and ankle joints observed in the patient and the healthy participant are shown in the graphs (Fig. 1-4). The analysis revealed that hip flexion and extension amplitudes in the operated (left) leg were narrower than in the right leg (Fig. 1, Table 2).

The analysis showed that the amplitude of left lower leg flexion and extension at the knee joint during one gait cycle was reduced in the patient, as compared with the healthy subject (Fig. 2, Table 3).

Ankle flexion and extension amplitudes during walking were smaller for the operated leg than for the right healthy leg (Fig. 3, Table 4).

The amplitude of movement in the lower leg joints was reduced due to the impaired gait pattern and a reduction in the passive and active range of motion in the lower leg, which again could be explained by immobilization after surgery (the need to wear an orthosis/brace) and the lack of adequate movement stereotype. The range of motion in the joints may be affected by the choice of the donor site for anterior cruciate ligament reconstruction. Further research is needed to test this hypothesis.
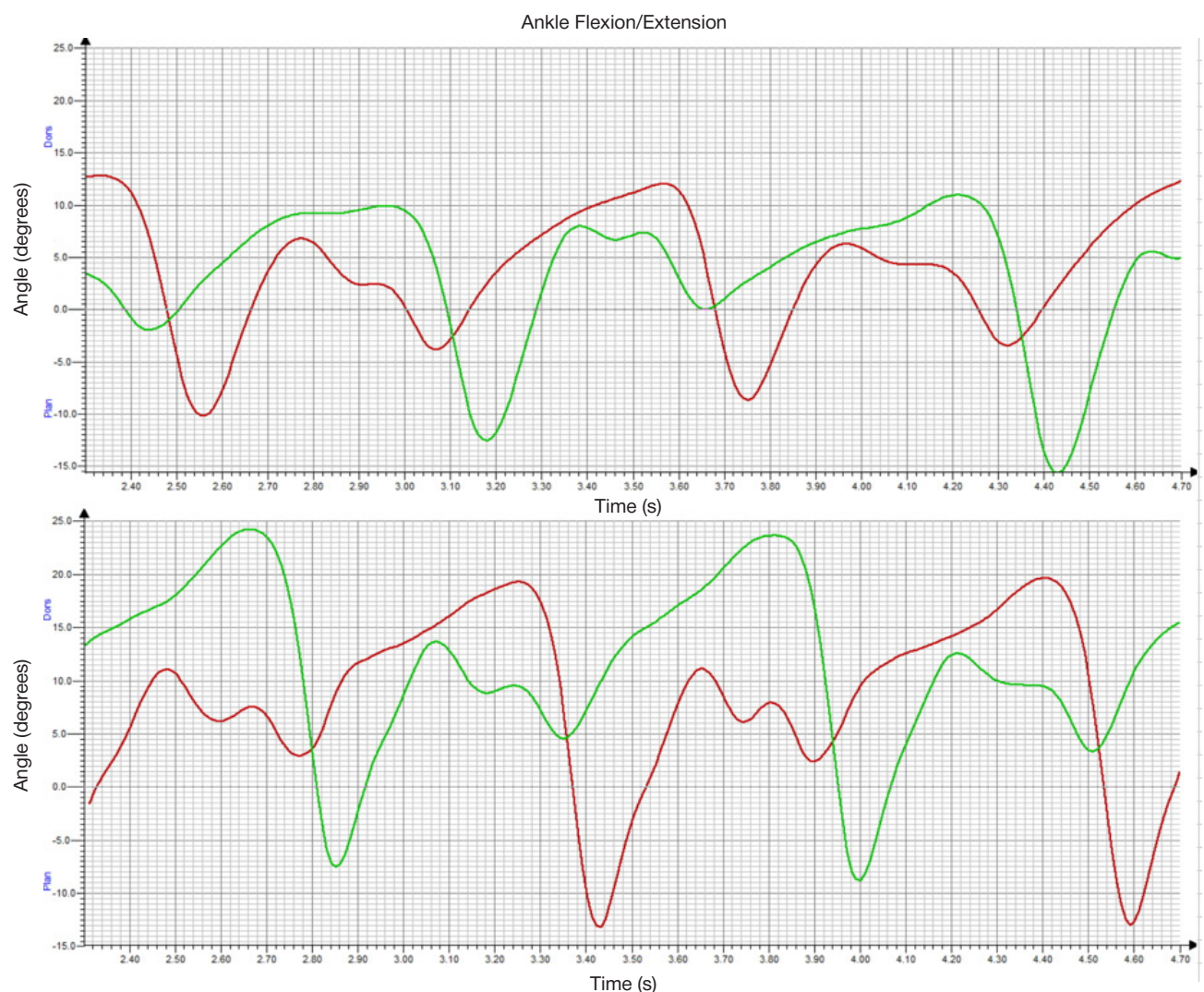

Fig. 3. Ankle flexion and extension during one cycle in the patient with injuries to the knee ligament apparatus (top) and the healthy subject (bottom) 
Table 4. Mean ankle extension and flexion angles and amplitudes during one gait cycle in the patient with injuries to the knee ligament apparatus and the healthy subject

\begin{tabular}{|c|c|c|c|c|}
\hline \multirow{2}{*}{} & \multicolumn{2}{|c|}{ Patient with injured knee ligament apparatus } & \multicolumn{2}{|c|}{ Healthy subject } \\
\cline { 2 - 5 } & Left leg & Right leg & Left leg & Right leg \\
\cline { 2 - 5 } & & \multicolumn{3}{|c|}{$\mathrm{Me}\left[\mathrm{P}_{25} ; \mathrm{P}_{75}\right]$} \\
\hline \multirow{2}{*}{ Angle 1 } & $-8,24$ & $-15,65$ & $-9,59$ & $-9,18$ \\
\cline { 2 - 5 } & {$[-9,41 ;-7,01]$} & {$[-17,19 ;-14,37]$} & {$[-12,05 ;-7,8]$} & {$[-10,39 ;-8,52]$} \\
\hline \multirow{2}{*}{ Angle 2 } & 13,48 & 10,79 & 19,76 & {$[22,11 ; 24,22]$} \\
\cline { 2 - 5 } & {$[12,99 ; 14,71]$} & {$[9,25 ; 11,47]$} & {$[18,26 ; 20,49]$} & 32,26 \\
\hline \multirow{2}{*}{$\Delta$} & 21,9 & 26,21 & 29,33 & {$[30,83 ; 33,91]$} \\
\hline
\end{tabular}

We also found that the degree of left knee joint rotation was significantly lower than in the right knee joint (Fig. 4, Table 5). Rotation asymmetry in the knee joint was observed in the healthy subject, too, but it was slight.

\section{Discussion clinical case}

A study reported the use of MCA during a single leg hop test for assessing recovery of static and locomotor function in athletes after anterior cruciate ligament repair [12]. The following parameters were evaluated: knee flexion at initial contact, peak knee flexion, knee flexion range of motion, and knee valgus range of motion in the frontal and sagittal planes. The speed and rhythm of the gait were not studied. The authors concluded that MCA could be recommended as a simple and accurate method for assessing knee joint stability and predicting changes of returning to sports after anterior cruciate ligament reconstruction [12].

Another study employed MCA to assess the risk of injury in athletes following anterior cruciate ligament reconstruction
[13]. The researchers performed the motion analysis of leg movements and assessed stability of the knee joint during walking, running, kicking the ball with moderate force and ball lashing. In addition to the speed and rhythm of gait, the researchers measured the ratios of flexion and extension angles in the operated and healthy knees during running and ball kicking. The angular characteristics of movements were not studied. It was concluded that MCA could be used as independently and as a complementary tool for gait analysis [13].

Another study was conducted in female athletes with anterior cruciate ligament injury; MCA was applied to analyze the mean knee flexion and the mean valgus angles during the initial contact, the internal and external rotation angles of the knee joint, and the mean peak vertical ground reaction force. The anterior cruciate ligament injury was attributed to a combination of valgus loading and internal knee joint rotation [14].

In another publication, the mechanisms of a slip-catch injury to the anterior cruciate ligament were investigated using MCA. The following parameters were analyzed: the knee

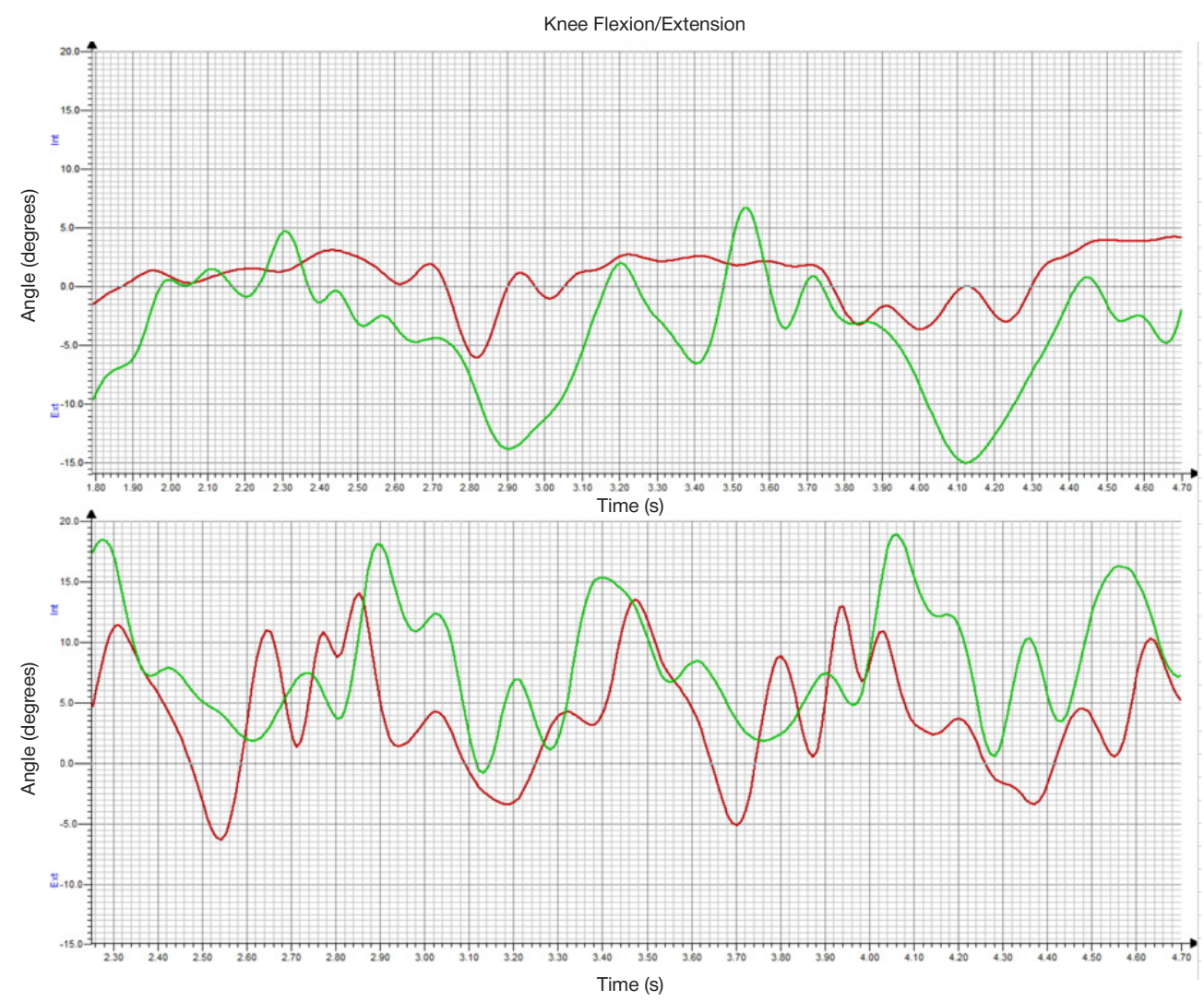

Fig. 4. Knee joint rotation during one gait cycle in the patient with injuries to the knee ligament apparatus (top) and the healthy subject (bottom) 
Table 5. Mean knee rotation angles and amplitudes during one gait cycle in the patient with injuries to the knee ligament apparatus and the healthy subject

\begin{tabular}{|c|c|c|c|c|}
\hline & \multicolumn{2}{|c|}{ Patient with injured knee ligament apparatus } & \multicolumn{2}{|c|}{ Healthy subject } \\
\hline & Left leg & Right leg & Left leg & Right leg \\
\hline & & & & \\
\hline \multirow{2}{*}{ Angle 1} & $-5,83$ & $-14,55$ & $-7,28$ & 0,57 \\
\hline & {$[-7,48 ;-4,96]$} & {$[-15,73 ;-13,37]$} & {$[-8,23 ;-5,12]$} & {$[-0,64 ; 1,16]$} \\
\hline \multirow{2}{*}{ Angle 2} & 2,41 & 4,12 & 14,27 & 17,78 \\
\hline & {$[1,78 ; 2,79]$} & {$[3,13 ; 5,54]$} & {$[13,91 ; 15,17]$} & {$[17,02 ; 18,9]$} \\
\hline \multirow{2}{*}{$\Delta$} & 8,15 & 19,01 & 21,59 & 17,05 \\
\hline & {$[7,04 ; 9,58]$} & {$[17,2 ; 20,69]$} & {$[19,54 ; 22,75]$} & {$[16,03 ; 18,8]$} \\
\hline
\end{tabular}

flexion angle, the tibial internal rotation angle, and the mean knee valgus angle. Speed, rhythm and angular parameters of motion in the hip and ankle joints were not studied. The study concluded that valgus loading, internal knee joint rotation and abduction were significant contributors to the slip-catch injury [15].

Changes in movement characteristics observed in the operated knee (reduced hip, knee and ankle flexion and extension, reduced left knee rotation) are consistent with the findings of other researchers $[16,17]$.

\section{References}

1. Povrezhdenie svjazok kolennogo sustava. Klinicheskie rekomendacii. Obshherossijskaja obshhestvennaja organizacija «Associacija travmatologov-ortopedov Rossii (ATOR)». 2020; 36 s. Russian.

2. Korolev AV, Afanasev AP, llin DO, Gerasimov DO, Ryazancev MS, Kadancev PM. Povrezhdenija zadnej krestoobraznoj svjazki: biomehanika, osnovnye napravlenija diagnostiki, lechenija profilaktiki vtorichnogo osteoartrita. Genij ortopedii. 2020; 26 (3): 413-8. DOI: 10.17116/hirurgia2020091130. Russian.

3. Fedulova DV, Yamaletdinova GA. Metody ocenki processa vosstanovlenija posle rekonstrukcii perednih krestoobraznyh svjazok kolennogo sustava. Nauchno-sportivnyj vestnik Urala Sibiri. 2018; 1 (17): 68-85. Russian.

4. Razvalyaeva DV, Razvalyaev AS, Eremushkin MA, Styazhkina EM. Sravnitel'naja ocenka jeffektivnosti konservativnoj i operativnoj taktiki lechenija pacientov posle travmy perednej krestoobrazno svjazki s ispol'zovaniem robotizirovannoj mehanoterapevticheskoj sistemy "CON-TREX". Vestnik vosstanovitel'noj mediciny. 2019; 5: 35-39. Russian.

5. Valiev YeYu, Hakimov RN, Ubajdullaev BS. Sovremennyj vzgljad na lechenie kompleksnyh povrezhdenij svjazok kolennogo sustava. Vestnik jekstrennoj mediciny. 2015; 2: 81-84. Russian.

6. Ma Y, Soatto S, Košecká J, Sastry SS. An invitation to 3D vision. From Images to Geometric Models. Interdisciplinary Applied Mathematics. New York: Springer, 2004.

7. Wang I, Hu W, Tan T. Recent developments in human motion analysis. Pattern Recognition. 2003; 36 (3): 585-601. DOl: 10.1016/S0031-3203(02)00100-0.

8. Skvorcov DV. Metodika issledovanija kinematiki dvizhenij i sovremennye standarty. Videoanaliz. Lechebnaja fizkul'tura i sportivnaja medicina. 2012; 12: 4-10. Russian.

9. Cappozzo A, Cappello A, Croce UD, Pensalfini F. Surface-marke cluster design criteria for 3-D bone movement reconstruction. IEEE Transactions on Biomedical Engineering. 1997; 44 (12): 116574. DOI: $10.1109 / 10.649988$.

10. Hewett TE, Torg JS, Boden BP. Video analysis of trunk and knee motion during non-contact anterior cruciate ligament injury in female athletes: lateral trunk and knee abduction motion are combined components of the injury mechanism. British Journal

\section{CONCLUSION}

3D MCA is an informative method for the analysis of subtle changes in the biomechanics of walking in patients with anterior cruciate ligament injuries. The method generates valuable data about the amplitude and angular parameters of motion, and the speed and rhythm of gait.

Further research is needed to clarify how long the pathologic changes to the gait may persist and whether they can be managed through rehabilitation. of Sports Medicine. 2009; 49 (6): 417-22. DOI: 10.1136/ bjsm.2009.059162.

11. Asaeda M, Nakamae A, Hirata K, Kono Y, Uenishi H, Adachi N Factors associated with dynamic knee valgus angle during single-leg forward landing in patients after anterior cruciate ligament reconstruction. Asia-Pacific Journal of Sports Medicine, Arthroscopy, Rehabilitation and Technology. 2020; 24 (22): 56-61. DOI: 10.1016/j.asmart.2020.07.002.

12. Welling W, Benjaminse A, Seil R, Lemmink K, Gokeler A. Altered movement during single leg hop test after $A C L$ reconstruction: implications to incorporate 2-D video movement analysis for hop tests. Knee Surgery Sports Traumatology Arthroscopy. 2018; 26 (10): 3012-9. DOI: 10.1007/s00167-018-4893-7.

13. Preobrazhenskij VYu, Zinovev OV, Sidorenko EV, Galuhin WV, Vnukov DV, Preobrazhenskij AV, i dr. Ocenka fizicheskogo sostojanija sportsmenov posle plastiki perednej krestoobraznoj svjazki s cel'ju preduprezhdenija povtornyh travm. Doktor.ru. 2011; 8 (67): 38-41. Russian.

14. Koga H, Nakamae A, Shima Yo, Iwasa J, Myklebust G, Engebretsen L, et al. Mechanisms for noncontact anterior cruciate ligament injuries: knee joint kinematics in 10 injury situations from female team handball and basketball. The American journal of sports medicine. 2010; 38 (11): 2218-25. DOI: 10.1177/0363546510373570.

15. Bere T, Mok K, Koga H, Krosshaug T, Nordsletten L, Bahr R. Kinematics of anterior cruciate ligament ruptures in World Cup alpine skiing: 2 case reports of the slip-catch mechanism. The American journal of sports medicine. 2013; 41 (5): 1067-73. DOI: 10.1177/0363546513479341.

16. Clark N, Forshey T, Mulligan I, Kindel C. Knee mechanics during a change of direction movement in division I athletes following full return to sport from anterior cruciate ligament reconstruction. Physical Therapy in Sport. 2018; 35 (4): 75-78. DOI: 10.1016/j. ptsp.2018.11.008

17. Sharifmoradi $K$, Karimi M, Hoseini $Y$. Evaluation of the Asymmetry of Leg Muscles Forces in the Subjects with Anterior Cruciate Ligament Reconstruction. The Journal of Knee Surgery. 2019; 34 (4): 357-62. DOI: 10.1055/s-0039-1695703. 


\section{Литература}

1. Повреждение связок коленного сустава. Клинические рекомендации. Общероссийская общественная организация "Ассоциация травматологов-ортопедов России (АТОР)». 2020; 36 c.

2. Королев А. В., Афранасьев А. П., Ильин Д. О., Герасимов Д. О., Рязанцев М. С., Каданцев П. М. Повреждения задней крестообразной связки: биомеханика, основные направления диагностики, лечения и профилактики вторичного остеоартрита. Гений ортопедии. 2020; 26 (3): 413-8. DOI: 10.17116/ hirurgia2020091130.

3. Федулова Д. В., Ямалетдинова Г. А. Методы оценки процесса восстановления после реконструкции передних крестообразных связок коленного сустава. Научноспортивный вестник Урала и Сибири. 2018; 1 (17): 68-85.

4. Разваляева Д. В., Разваляев А. С., Еремушкин М. А., Стяжкина Е. М. Сравнительная оценка эффеккивности консервативной и оперативной тактики лечения пациентов после травмы передней крестообразной связки с использованием роботизированной механотерапевтической системы "CONTREX". Вестник восстановительной медицины. 2019; 5: 35-39.

5. Валиев Э. Ю., Хакимов Р. Н., Убайдуллаев Б. С. Современный взгляд на лечение комплексных повреждений связок коленного сустава. Вестник экстренной медицины. 2015; 2: 81-84.

6. Ma Y, Soatto S, Košecká J, Sastry SS. An invitation to 3D vision. From Images to Geometric Models. Interdisciplinary Applied Mathematics. New York: Springer, 2004.

7. Wang I, Hu W, Tan T. Recent developments in human motion analysis. Pattern Recognition. 2003; 36 (3): 585-601. DOI: 10.1016/S0031-3203(02)00100-0.

8. Скворцов Д. В. Методика исследования кинематики движений и современные стандарты. Видеоанализ. Лечебная физкультура и спортивная медицина. 2012; 12: 4-10.

9. Cappozzo A, Cappello A, Croce UD, Pensalfini F. Surface-marker cluster design criteria for 3-D bone movement reconstruction. IEEE Transactions on Biomedical Engineering. 1997; 44 (12): 116574. DOI: 10.1109/10.649988.

10. Hewett TE, Torg JS, Boden BP. Video analysis of trunk and knee motion during non-contact anterior cruciate ligament injury in female athletes: lateral trunk and knee abduction motion are combined components of the injury mechanism. British Journal of Sports Medicine. 2009; 49 (6): 417-22. DOI: 10.1136/ bjsm.2009.059162.

11. Asaeda M, Nakamae A, Hirata K, Kono Y, Uenishi H, Adachi N. Factors associated with dynamic knee valgus angle during single-leg forward landing in patients after anterior cruciate ligament reconstruction. Asia-Pacific Journal of Sports Medicine, Arthroscopy, Rehabilitation and Technology. 2020; 24 (22): 56-61. DOI: 10.1016/j.asmart.2020.07.002.

12. Welling W, Benjaminse A, Seil R, Lemmink K, Gokeler A. Altered movement during single leg hop test after $A C L$ reconstruction: implications to incorporate 2-D video movement analysis for hop tests. Knee Surgery Sports Traumatology Arthroscopy. 2018; 26 (10): 3012-9. DOI: 10.1007/s00167-018-4893-7.

13. Преображенский В. Ю., Зиновьев О. В., Сидоренко Е. В., Галухин В. В., Внуков Д. В., Преображенский А. В., и др. Оценка физического состояния спортсменов после пластики передней крестообразной связки с целью предупреждения повторных травм. Доктор.ру. 2011; 8 (67): 38-41.

14. Koga H, Nakamae A, Shima Yo, Iwasa J, Myklebust G, Engebretsen L, et al. Mechanisms for noncontact anterior cruciate ligament injuries: knee joint kinematics in 10 injury situations from female team handball and basketball. The American journal of sports medicine. 2010; 38 (11): 2218-25. DOI: $10.1177 / 0363546510373570$.

15. Bere $T$, Mok K, Koga H, Krosshaug $T$, Nordsletten L, Bahr R. Kinematics of anterior cruciate ligament ruptures in World Cup alpine skiing: 2 case reports of the slip-catch mechanism. The American journal of sports medicine. 2013; 41 (5): 1067-73. DOI: 10.1177/0363546513479341.

16. Clark N, Forshey T, Mulligan I, Kindel C. Knee mechanics during a change of direction movement in division I athletes following full return to sport from anterior cruciate ligament reconstruction. Physical Therapy in Sport. 2018; 35 (4): 75-78. DOI: 10.1016/j. ptsp.2018.11.008

17. Sharifmoradi K, Karimi M, Hoseini Y. Evaluation of the Asymmetry of Leg Muscles Forces in the Subjects with Anterior Cruciate Ligament Reconstruction. The Journal of Knee Surgery. 2019; 34 (4): 357-62. DOI: 10.1055/s-0039-1695703. 